Article

\title{
Experts in Government: What for? Ambiguities in Public Opinion Towards Technocracy
}

\author{
Ernesto Ganuza ${ }^{1, *}$ and Joan Font ${ }^{2}$ \\ ${ }^{1}$ Institute of Public Goods and Policies, Spanish National Research Council (CSIC), 28037 Madrid, Spain; \\ E-Mail: ernesto.ganuza@csic.es \\ 2 Institute of Advanced Social Studies, Spanish National Research Council (CSIC), 14004 Cordoba, Spain; \\ E-Mail: jfont@iesa.csic.es \\ * Corresponding author
}

Submitted: 30 April 2020 | Accepted: 9 September 2020 | Published: 17 December 2020

\begin{abstract}
Technocratic governments and similar systems that give more voice to experts in the decision-making process are one of the potential alternatives to traditional representative party government. These alternatives have become increasingly popular, especially in countries where strong political disaffection and previous favourable pro-expert attitudes exist simultaneously. The Spanish case is one of these settings, with the emergence of a political party, Ciudadanos (Citizens), that represents these ideas. This article contributes to the understanding of public opinion support for an expert government, its main motives, and social supports. We claim that experts are not so much a decision-making alternative as they are a desired piece of the decision-making process. Support for a more significant role for experts comes especially from those that credit them with ample technical capacities, but most citizens want them to work as a piece of representative government, not as an alternative to it. The article combines two types of evidence: A survey of a representative sample of the population, including innovative questions about support to expert governments, and 10 focus groups that allow a more in-depth comprehension of the support (and criticism) of an increased role for experts. The results provide a nuanced picture of the types of expert involvement sought and their respective social support.
\end{abstract}

\section{Keywords}

democracy; experts; government; populism; representation; technocracy

\section{Issue}

This article is part of the issue "Varieties of Technocratic Populism around the World" edited by Petra Guasti (Institute of Sociology of the Czech Academy of Sciences, Czech Republic) and Lenka Buštíková (Institute of Sociology of the Czech Academy of Sciences, Czech Republic / Arizona State University, USA).

(C) 2020 by the authors; licensee Cogitatio (Lisbon, Portugal). This article is licensed under a Creative Commons Attribution 4.0 International License (CC BY).

\section{Introduction}

Significant theoretical research of the last decades highlights an increased desire for 'unmediated' political processes that challenge party democracy (Caramani, 2017; Urbinati, 2014). For some years the debate has been oriented to empirically linking this trend with the study of populist attitudes among citizens. Literature has demonstrated the existence of significant support for a political system away from the central values of party democracy. Furthermore, studies have found a percentage of the population with populist attitudes that are significantly linked to a preference for voting populist parties (Akkerman, Mudde, \& Zaslove, 2014, pp. 14-18).

The striking point in the research of populism attitudes has been the (unexpected) link between populism attitudes with those of elitism. Akkerman, Mudde, and Zaslove (2014, p. 18) note that people who may be attracted to populist parties score high on both the populist and elitist scales. They mentioned that features of some populist parties such as "charismatic leadership, centralized parties, the so-called outsider status of the 
leader" may also appeal to those with higher elitist attitudes. Theoretically, the relationship between populism and elitism has been built on the links that technocracy has with the same populism's ideals, because it entails a similar unitary and idyllic vision of society, advocating unmediated political relations (Caramani, 2017). Both would be in opposition to the classic conception of party democracy, questioning (1) the role of mediation of the parties and (2) the procedural conception of democratic legitimacy (Bickerton \& Invernizzi Accetti, 2017, p. 190).

From the supply side, it seems that populism and elitism (via technocracy) could be combined. Recent studies have shown the emergence of new political parties bringing together both populism and technocracy ideals, the so-called technocratic populism (Bickerton \& Inverzzini Accetti, 2018; de la Torre, 2013). Buštíková and Guasti $(2019$, p. 304) say that technocratic populism "strategically uses the appeal of technocratic competence and weaponizes numbers to deliver a populist message. It combines the ideology of expertise with a populist political appeal to ordinary people."

From this perspective, we could think that the use of "the ideology of expertise" (technocracy) allows populist parties to reject party democracy from a rational grounding (science). However, from demand side studies, the use of the term technocracy is not so clear. Many studies have found evidence of an important presence of technocratic attitudes in various countries; however, they were attitudes often related to other political procedures such as citizen participation or party elections (Font, Wojcieszak, \& Navarro, 2015; Webb, 2013). An international comparative research (Bertsou \& Pastorella, 2017) showed a high presence of technocratic attitudes among the European population. However, more recent research, including a new methodology to analyse such attitudes, revealed a significantly lower incidence (Bertsou \& Caramani, in press), reducing the percentage of technocratic attitudes among the population dramatically. We can conclude that the most recent studies on technocratic attitudes among individuals are not conclusive. The ideology of expertise can be used by populist parties to legitimate a rejection of party democracy, but it is no entirely clear to what extent individual technocratic attitudes will support it.

This article aims to analyse in detail the technocratic attitudes of the population to shed light on the implications they have on the political regime and to what extent their presence implies a rejection of party democracy. Most of the studies that have shown an indication of some form of technocratic attitudes among the population (Bertsou \& Pastorella, 2017; Hibbing \& Theiss-Morse, 2002) have based their evidence on a single statement: 'Having experts, not government, make decisions according to what they think is best for the country' as it appears in the European Values Survey. Following the results of the most recent research (Bertsou \& Caramani, in press), we may question whether this statement embraces all the dimen- sions of the matter related to a government of experts. If we consider the analytical distinction elaborated by Bickerton and Invernizzi Accetti (2017), the question may tell us more about the different roles that political agents have in the mediation between citizens and the state than about the procedures of representative democracy. It is very illustrative that in these investigations the relationship between technocratic attitudes and political distrust in government is always high. Even if technocracy, as an ideology of expertise, is not the only way to highlight anger towards party politics, the presence of technocratic attitudes among people could be a way to criticize the functioning of the democracy, rather than a rejection of the principles of representative democracy. In order to develop this argument, we will show the result we obtained by taking the question used to identify technocratic attitudes as it appears in the European Values Survey, and then contrast those results with a question that mentions different ways to engage experts in the government (as advisers or rulers).

The study is based on a combination of quantitative and qualitative information which comes from the Andalusia region in Spain in 2015. The result of the qualitative research allowed us to understand the importance that the problem of the procedural conception of democratic legitimacy acquired for citizens when speaking about technocracy. The representative survey adds questions in order to distinguish this problem directly. The results show that the majority of the population wants to listen to what experts have to say without changing the procedural legitimacy of representative decision making. Confidence in the skills of experts (capacity) and, to a lesser extent, preference for a pro-technocratic party (Ciudadanos) are the principal factors linked to supporting a more substantial role for experts in government.

In the next section, we will review the relations between public opinion and views on technocracy. The following section describes and justifies the methodological strategy developed in this article. Subsequently, we engage with the empirical analysis; we start off by looking at the content from the focus groups and use this as the basis for justifying the different views on experts, which are then examined in the succeeding two quantitative sections (firstly descriptively, and then by regression analysis). The article closes with a discussion of the results and their implications.

\section{Technocracy and Political Procedures}

The study of technocratic attitudes among citizens is not recent. The value of technocracy in politics has been praised because it draws together elements believed to be characteristic of good government, such as distance from clientelist networks and concern with efficiency. The result would be a form of "stealth democracy," a thinly-veiled desire by governments to avoid ideological conflict and situate politics in the domain of impartial and neutral analysis (Hibbing \& Theiss-Morse, 
2002). Scholars have found growing support for stealth democracy among citizens in several European countries, where it apparently enjoys a large social acceptance (Font et al., 2015; Webb, 2013).

The problem is that these studies are not entirely conclusive. The same works find similar support for other forms of political organization related to citizen participation or the classic representative model. Bertsou and Pastorella (2017) then analyse technocratic attitudes in Europe based on the recent link found between populism and technocracy. They understand their presence in contrast to the current political elites, so "a preference for independent expertise also entails a belief that the people are unable to select worthy decisionmakers through the current democratic system" (Bertsou \& Pastorella, 2017, p. 433). Therefore, they think that technocratic attitudes will be influenced by individual evaluation of representative democracy in an expected negative relation.

Citizen distrust towards the functioning of partybased politics used to be thought of as an attitude that favoured the desire of the citizenry for greater involvement in decision-making processes (Norris, 2011). This was also the postmaterialist thesis with which Inglehart (1990) linked political disaffection to a greater wish to be involved in political affairs. The studies on stealth democracy were the first to point out that the data indicated more of an inclination towards technocratic modes of government, aimed at making decisions efficiently. The link between populism and technocracy backed by empirical studies (Akkerman et al., 2014; Bertsou \& Caramani, in press) has displaced that relationship, suggesting a desire for modes of less openly democratic governance.

The debate around technocracy has been successful in raising the importance that expertise has in contemporary societies and questioning to what extent its desire on the part of citizens can effectively end up displacing the principles of liberal democracy, as it has been suggested by the analysis of the new parties characterized by technocratic populism (Bickerman \& Inverzzini Accetti, 2018; Buštíková \& Guasti, 2019). It is often taken for granted that technocracy, the ideology of expertise, implies a political relationship 'without mediation' whereby more experts mean fewer parties, as if this were a zero-sum game (Urbinati, 2014). However, the role that technical skills and expertise have played in the development of contemporary societies (Radaelli, 1999; Turner, 2001) may suggest that they are valued positively by citizens, where the presence of more experts does not imply directly fewer parties, but rather more knowledge and science in the execution of some government tasks. Public acceptance of technical skills and expertise could be owed also to a change in the nature of politics, where knowledge has become a key element (Fischer, 1990). We can, from this perspective, understand the role that some individuals attribute to experts (because of their technical skills and expertise) as a facilitator for a rational framework, removed from all that parties are criticised for (egoism, loyalty issues, etc.; Radaelli, 1999).

This demand on technical skills and expertise in the government can be approached from different arguments. On the one hand, it is advocated by those driven by a desire for impartiality, aside from political disputes (Hibbing \& Theiss-Morse, 2002). Commitment to a growing role for experts would mean identifying politics with the idea of truth-government as epistocracy (Urbinati, 2014). Here, experts are expected to rule. On the other hand, other positions back the relevant role of technical skills as an element which supports the government's tasks. From this perspective, it may be considered that contemporary politics simply cannot do without facts and experts in a complex world (Eriksen, 2011; Radaelli, 1999). Here, experts are expected to advise. This means that the inclination towards technocracy may involve (1) replacing elections so that decisionmakers are experts or (2) consulting experts in the decision-making process to make politics more efficient.

This distinction is absent in the majority of studies which seek to shed light on society's attitudes to technocracy. If we empirically consider the two analytical key features that Bickerton and Invernizzi Accetti (2017) used to identify party democracy-political mediation and the procedural conception of political legitimacywe can broaden and better approximate the meaning that technocracy can have for citizens. The general question used to link technocracy and populism, as well as concluding that citizenship legitimates a technocratic government, refers us to the first feature that characterizes party democracy (political mediation). According to Bickerton and Invernizzi Accetti (2017), this function assumes that parties reflect both material and ideal social divisions and are politically constituted as competitive visions of the common good. Hibbing and Theiss-Morse (2002) convincingly analysed the relationship between the desire for more experts and citizens' negative evaluation of disputes between political representatives. The typical question posed to emphasise technocratic attitudes tends to focus on comparing the merits of experts to those of other actors (parties and political leaders) who generate little trust. It is therefore not strange to find a negative relationship between technocratic attitudes and representative democracy in empirical studies (Bertsou \& Pastorella, 2017). But it is worth asking whether this relationship (political mediation) is directly linked to the rejection of the political procedures that characterize party democracy, where experts are expected to advise. Considering the procedures means keeping in mind that the results of party democracy do not depend on a pre-political conception of truth, but rather depend on a more complex and diffuse process, in which the majority is obtained from the elections and subsequent negotiations between different agents (Bickerton \& Invernizzi Accetti, 2017). If this is the case, we might think that the high presence of technocratic attitudes may be based on the trust that cit- 
izens have in experts, and less on a distrust of the procedural principles of liberal democracy, such as elections. In order to get closer to the value that citizens give to the political procedures of democracy by parties, we will compare the support of the public for a decision-making procedure that includes experts as rulers and as advisers.

The question in this research is based on how experts are valued by society. In all surveys, support for scientists is usually greater than that for politicians (Krause, Brossard, Scheufele, Xenos, \& Franke, 2019). The expert, contrary to the politician, is valued on the basis of merits and qualities which do not depend on their political position, but rather on their knowledge and technical skills. This confers on them a significant prestige, based on its singular capacities, in contrast with politicians who forge their success by means of capacities founded on privilege, not prestige.

Thus, our objective is to distinguish citizens' support for a government where experts are present from that for one where they are effectively in charge of its political steering. Are we talking about a government of experts as an alternative to a representative government or do we mean an accompanying presence of experts within the context of a representative democracy? In view of this framework, we formulate the following hypotheses:

$\mathrm{H1}$ : Preferences for experts in government are reduced when their specific role in the political decision-making process is stressed. Many citizens who support the presence of experts in government, do not support that they make final binding decisions.

$\mathrm{H} 2$ : All preferences for experts in government are related to their perceived technical skills (capacity) to resolve public affairs.

H3: All preferences for experts in government are related to support for a pro-technocratic party (Ciudadanos).

H4: The explanatory factors that support a government in which experts advise will differ from those supporting a government in which they make binding decisions. For example, leftist voters may not be against experts advise, but will reject a government lead by experts.

\section{Methodology and Data}

We have combined quantitative and qualitative research in a mix method strategy. On the one hand, qualitative research allows us to look deeper into the arguments used by people when they discuss the political crisis and the alternatives they envision. A qualitative investigation with focus groups gives participants time to think through answers and engage in a discussion with others. In our case, it was through the focus groups that we were able to appreciate that the problem of techno- cratic attitudes was more complex; when talking about the suitability of experts for political positions, among other things because they are considered to be better prepared, the question of the legitimacy of the political results obtained always arose as an insurmountable problem for the majority. By using this method, we elicit what Stoker, Hay, and Barr (2016) call 'slow thinking,' giving people the necessary space to reflect on complex issues. On the other hand, the survey will enable us to analyse citizens' preferences about different political processes (direct democracy, technocracy, and representative democracy) and will, in particular, allow us to test the conclusions of the qualitative study on technocracy views on a representative sample of the population.

The focus groups took place between March and September 2015. There were 10 in total, with 6 to 8 participants of homogenous profiles in each group in order to facilitate a debate. The sample framework design is based on variability criteria related to socio-political positions. Six groups were designed according to the education, professional and associative profile of the participants, as well as their age (high income and high-level education group vs low income and low-level education; group of young university students vs group of young people without any studies; group of activists in traditional organisations vs groups of young alter-globalist activists). A further four groups were designed with the aim of directly recording the opinions of supporters of the four principal political parties at that moment-PSOE (Socialist Workers' Party, centre-left), PP (People's Party, right), Ciudadanos (Party of the Citizenry, centre-right), and Unidas Podemos (UP, United We Can, left). That's to say, we aimed for variability, at the same time as ensuring we could study some positions in particular detail. Details about the make-up of groups appear in Ganuza and Font (2018). The distinction between politicized and non-politicized groups is based on previous studies which indicate how significant personal experience related to politics and resources available to individuals are when evaluating technocratic attitudes (Bertsou \& Pastorella, 2017). Data was transcribed and analysed using Atlas.ti. All references to 'experts' were codified, with the objective of identifying the key issues for the study: (1) the value of experts in politics; and (2) their role in government.

The survey uses a probability sample. The fieldwork was conducted between November and December 2015 (EP-1510 IESA/CSIC). The 1081 interviews carried out, with their corresponding weighting, are an adequate representation of the region's adult population. The survey results have an estimated level of absolute maximum sampling error of $\pm 3.1 \%$ for a $95 \%$ confidence interval. Participants completed the questionnaire online (53\%) or by phone (47\%).

Andalusia is a region that provides an interesting context for the study of views on technocracy; there is an elevated level of distrust in institutions and an interest in politics situated below European standards-two 
indicators related to the increase of technocratic attitudes amongst the population (Ganuza \& Font, 2018). The region shares common characteristics with the rest of Spain with regards to the high level of positive responses to the traditional question about support for an expert government (Font et al., 2015). Moreover, it is there that Ciudadanos, a political force which defends technocratic arguments, first gained an important position in elections, becoming the chief political ally of the Andalusian socialist government after the elections in December 2015. The party's stance shares some characteristics with what Buštíková and Guasti $(2019$, p. 302) call technocratic populism, such as 'the appeal of technical expertise' and 'promising to run the state as a firm.' Although a more in-depth study of the party's discourse would be necessary to find out if it indeed fits in this category, their defence of the 'government of the best' is a constant feature. Within this context, where Ciudadanos and its proposals are deemed relevant and enjoy sufficient visibility, a particularly interesting setting emerges for the study of relations between a political force and citizens' attitudes to technocracy. Lastly, this Andalusian investigation is based on previous work about the Spanish case (Font et al., 2015; Ganuza, García-Espín, \& de Marco, 2017) which has facilitated the construction of the hypotheses tested here through the inclusion of additional new questions in the survey.

\section{Qualitative Empirical Evidence: Experts vs. Democracy}

All focus groups openly criticized the current state of democracy and in particular the way political parties operate. But democracy, as a political framework, was not questioned. Parties are responsible for distorting the political game of representation, with internal relations governed by loyalty to leaders where merit is absent. Such a system nourishes corruption and clientelism, and the emergence of politicians 'who are not qualified.' This is a core point in the debate surrounding the political crisis and is the reason why so many participants value merit and knowledge in politics, and connect them to experts.

For example, for supporters of the conservative party (PP), the problem was the absence of politicians with a professional profile who 'should have worked in something else beforehand.' However, the value of 'knowledge' and 'merit' as a crucial variable to evaluate politics is, albeit with varying intensity, very similar in the majority of focus groups. For supporters of the socialist party, politicians also 'should know more.' People who have knowledge are people who have studied and have had a job because they know how to do something, as opposed to politicians. They are usually identified by participants as experts-people with technical skills.

Young people represent the part of civil society which most strongly defends experts. For young people without studies, it is experts who 'know the truth.' For them, anyone aspiring to rule should emulate the meritocracy inherent in a professional career, in other words 'in order to rule one should have one or two degrees and be experienced.' University students were also manifestly in favour of technical skills and expected knowledge from those who work in politics. Only precarious and low qualified workers had a discourse which rejected meritocracy as the backbone of politics.

The importance attached to knowledge and merit may partially explain the allure of experts in politics. They reflect the idea of a profession underpinned by technical skills and capacities, and free of ideological bias. The debate amongst participants of most groups always featured the ideal technocratic scenario pointed out by Hibbing and Theiss-Morse (2002)-impartial and contrasted by almost everyone with the way politics functions normally.

That said, participants' conversations in all groups highlighted that it is one thing to talk about political efficiency, where knowledge and expertise should be present, and quite another to define a government just around experts, opposed to the procedural conception of democratic legitimacy, which resides with citizenry and elections. Here, notable differences emerged amongst the groups, but the debate moved towards defining the significance that experts should have in a democratic framework. The global response to a government of experts regarding democratic legitimacy was more negative than positive. For most, it is a question of avoiding 'clientelism' and 'favouritism,' not so much of organising a government with a uniquely expertise dimension. The two most polarised groups in this respect are young university students and precarious workers. The latter do not trust the figure of an expert who is cut off from reality and who 'does not have people in mind.' For them, a government of experts only cuts expenses and crunches numbers: 'if the numbers don't add up for the mathematician, we'll end up with nothing.' At the other extreme, we find the young university students. For them the issue of experts is important and they dedicate plenty of time to it in their conversations. They are convinced that a government should be chosen by 'the people' (elections), although some would want to combine a system of experts with the democratic standards of an eligible and revocable government, and speak of a political government (not formed of experts), but selected 'by public oppositions.'

This idealised vision of experts (in the politically most conservative groups and amongst young educated people) stands in contrast to that of the more progressive groups. For them, experts have an ideology and are indebted to a particular vision of society, amongst other reasons because 'they normally come from the upper classes, from well-off families.' For young people, from alter-globalists associations and supporters of left-wing parties, experts come hand-in-hand with academic qualifications, although this is separated from another valueexperience, real contact with people, which comes with 
having a job. With this differentiation (experts versus experience), the more leftist participants imply that any person without studies may have valuable experience without necessarily having specialised knowledge. For them, experts' knowledge has a place in government, but it only makes sense to consider the value of experts in public management when experts and experience are set apart, with the latter not only extant in the domain of those with the highest formal education.

Experts' knowledge is defended in quite a different way by more politically conservative groups (centreright voters and qualified workers). The rejection of an experts' government rests on a functional differentiation between politicians and experts: the former rule and the latter manage. The groups mount a radical defence of the role of experts and would even increase their role in detriment of that of politicians, reducing the scope of action that politicians currently have ('Why do we need so many politicians to move the mechanism of the state if there are magnificent civil workers who are trained, qualified and brilliant at doing so?'), but they never accept a government of only experts.

We can observe how some groups take a line of defending technocracy as an ideology of expertise, although none reject the idea that a democratic government should be elected and that therefore, there is no room for a government formed entirely of experts. In the very instant that procedures in democratic legitimacy are contemplated within perspectives on technocracy, participants' discourse shifts and the call for an increased role for experts is not accompanied by a desire that they should actually rule, only that they are there to be consulted. In the next section, we will look at this point in more detail, given that this tension has been taken into consideration in the survey.

\section{Quantitative Descriptive Evidence: The Apparent Charm of Experts}

The survey also shows that citizens have considerable support for a greater presence of experts in decisionmaking processes. Figure 1 reflects the significant backing enjoyed by experts, in contrast to what we may identify as the model of representative democracy (those who govern take decisions). As other studies have shown (Bertsou \& Pastorella, 2017), about half of the sample is fully supportive (8-10 agreement on a $0-10$ scale) of the possibility of important decisions being taken by independent experts, with the number increasing if instead of asking about taking decisions we speak of 'consulting.'

However, as already identified in the focus groups, when experts' increased role is compared with alternative political procedures to decision-making, support is attenuated (Figure 2): If instead of mentioning 'rulers,' we focus on the procedure that characterizes party democracy-elections-we find that support for elections is clearly stronger ( $62 \%$ choose a value from 8 to 10$)$ than for experts taking important political decisions (46\%).

A similar pattern is observed if we make the comparison with participative mechanisms. For example, decision taking in assemblies enjoys more high support ( $52 \%$ from 8 to 10 ) than experts making decisions ( $30 \%$ as opposed to $20 \%$ ). Support is only somewhat lower for referendums. As we saw with the focus groups, when we shift the question to a broader political procedural perspective, support for formulas based on experts is less substantial if we compare it with other decisionsmaking procedures.

This result can be better understood if we observe the precise role which citizens want experts to have in a hypothetical government. Following on from what

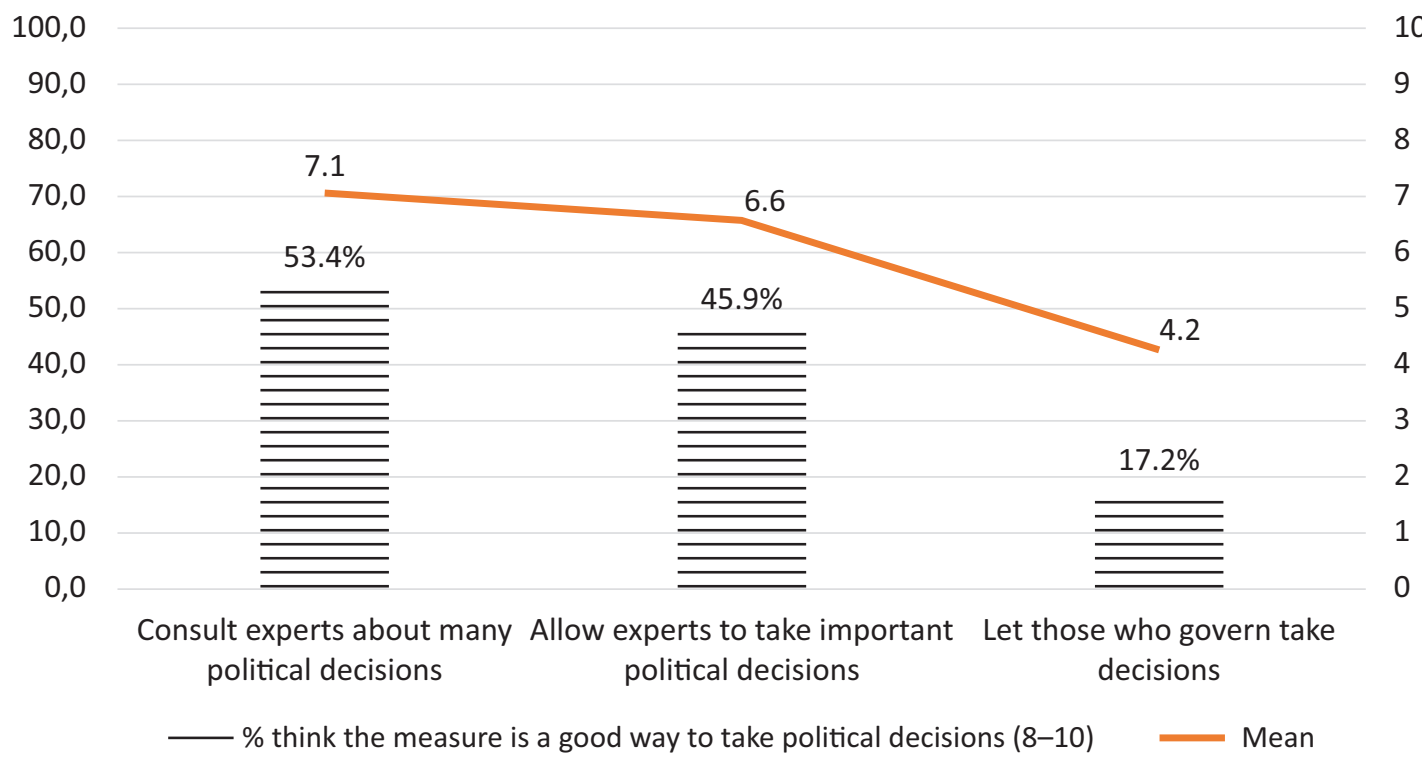

Figure 1. Agreement with expert role in government. 


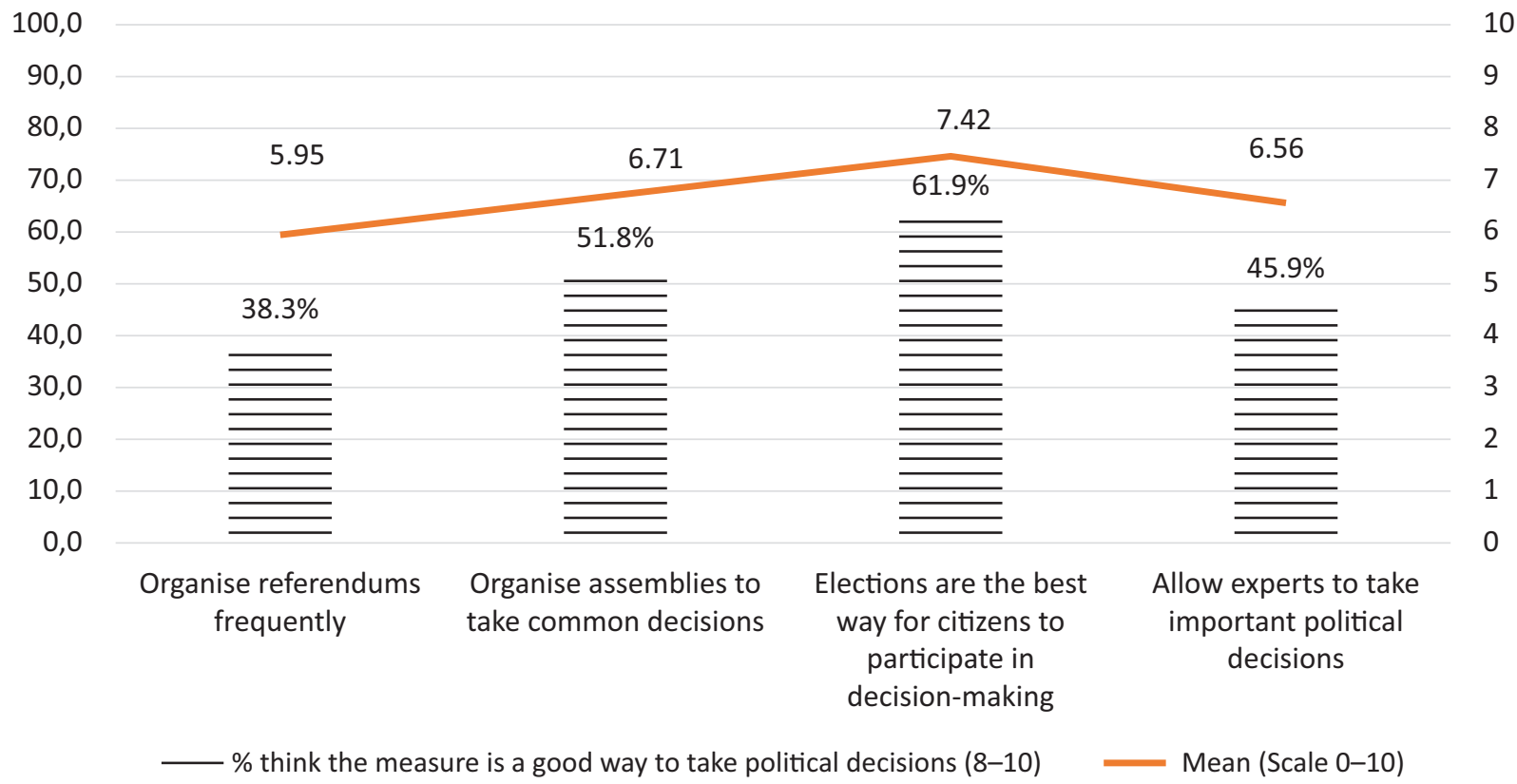

Figure 2. Support for alternative procedures to decision-making.

participants in the focus groups highlighted, survey respondents had to choose between the following three options: (1) forego experts altogether; (2) listen to them but do not have them take decisions; and (3) allow them to participate in decisions directly. The results show clearly that very few citizens think that experts are expendable (6.3\%), while the most common position is 'listen, but not decide' (66.3\%). Support for experts in government is notably lower (25.6\%). Our first hypothesis is therefore supported.

Social support to each of the positions is quite unevenly distributed. Thus, amongst those most reluctant to listen to experts, we find left-wingers and some of the social groups in a more precarious situation-profiles similar to those observed in the focus groups. On the contrary, those most in favour of an expert government are older people and voters of Ciudadanos. The regression analysis in the next section will enable us to analyse these differences in detail.

\section{Who Supports Experts and Why? Regression Analysis}

Support for an increased presence for experts changes if we look at generic support or at the possible functions of experts; it is therefore reasonable to expect that the underlying factors that explain these attitudes also differ. The majority of research carried out until now has analysed the first of these attitudes (Del Rio, Navarro, \& Font, 2016; Rapeli, 2016), and here we compare it with support for a scenario where experts are not only listened to but also take decisions.

We therefore use two dependent variables. Firstly, the affirmation 'allow experts to take political decisions' (scale 0 to 10). This question is similar to that used by most research about technocratic attitudes as it appears in the European Values Survey. Secondly, the question about what role experts should occupy in government, differentiating between those who are in favour of experts taking directly political decisions and those who hold different views (to be consulted or without any role). This question tries to capture the importance of political procedures, because participants have to choose between experts as rulers or advisers.

What factors help us to understand support to both attitudes? We include two main explanations and a wide set of control variables. Firstly, there is a variable which refers to the qualities of decision makers. According to Del Rio et al. (2016) the (perceived) qualities of the main actors in decision-making (experts, in our case) become an important explanatory factor. This argument fits in with the significance of skills attached to experts in the qualitative study and, in particular, their capacity based on merit and knowledge, which will consequently be the quality we use. Del Rio et al. (2016) explicitly acknowledge that one of the limitations of their work was the lack of data on citizens' perception of the qualities of experts. Our survey allows to analyse, on a scale of 0 to 10 , if this measure is important. Table 1 shows the descriptive characteristics of all the independent variables used.

Another important set of factors useful for understanding support for experts are political preferences. Although Hibbing and Theiss-Morse (2002) argued that people's support for political processes were independent of ideology, several works (Bengtsson \& Mattila, 2009; Bertsou \& Pastorella, 2017) have shown the impact of ideology, and in particular the difference between progressist and other values. We distinguish between leftist voters (positions $0-3$ on a $0-10$ scale), versus the rest. 
Table 1. Descriptive characteristics of the independent variables.

\begin{tabular}{|c|c|c|c|c|c|}
\hline Variable & Min & Max & Mean value & Standard dev. & Categories of answer \\
\hline Capacity (skills) of experts & 0 & 10 & 7 & 2.2 & Scale 0-10 \\
\hline Left ideology (0-3) & 0 & 1 & 0.22 & 0.41 & Categorical-0: No; 1: Yes \\
\hline Vote & 0 & 4 & - & - & $\begin{array}{l}\text { 0: Others (Reference category); 1: PP; } \\
\text { 2: Cs; 3: PSOE; 4: UP }\end{array}$ \\
\hline Efficacy, not debate & 1 & 4 & 3.2 & 0.8 & $\begin{array}{l}\text { Scale of 1: Strongly Agree; } \\
\text { to 4: Strongly Disagree }\end{array}$ \\
\hline Politics difficult for people like me & 1 & 4 & 2.5 & 0.9 & $\begin{array}{l}\text { Scale of } 1 \text { : Strongly Agree; } \\
\text { to } 4 \text { : Strongly Disagree }\end{array}$ \\
\hline Political trust & 0 & 40 & 14.5 & 9.4 & Additive scale 0-40 \\
\hline Social trust & 0 & 10 & 5.5 & 2.7 & Scale 0-10 \\
\hline Participation vs representation & 0 & 10 & 4.6 & 2.8 & $\begin{array}{l}\text { Bipolar scale } 0-10 \text { (0: participation; } \\
\text { 10: representation) }\end{array}$ \\
\hline No Materialism & 0 & 1 & 0.32 & 0.47 & 0: Materialists; 1 : non materialists \\
\hline Education & 1 & 5 & 2.3 & 2.21 & Scale 1-5 \\
\hline Age & 16 & 91 & 46.4 & 16.7 & Continuous \\
\hline
\end{tabular}

Moreover, in Spain a new political party, Ciudadanos, has emerged; both the party's discourse and the profile of its elites manifestly defend a greater presence of experts in the decision-making process (Lavezzolo \& Ramiro, 2017). Thus, we included vote recall in the last regional election as an independent variable.

The control variables introduced correspond to alternative explanations of preferences for political processes suggested by previous research:

- Views on how much debate versus efficacy there should be in our form of government (Hibbing \& Theiss-Morse, 2002). A scale of 'Strongly Agree' to 'Strongly Disagree' with the following statement: 'Institutions should focus on being efficient and dedicate less time to debating different points of view.'

- Internal political efficacy (degree of agreement with the statement 'politics are too difficult for people like me').

- Political trust is one of the basic underlying factors that explain preferences for representative or alternative political processes (Bengtsson \& Mattila, 2009; Rapeli, 2016; Bertsou \& Pastorella, 2017). We use an additive scale of the four traditional indicators of political trust available in the survey: overall confidence in political parties, central government, judicial power and political system. Cronbach's alfa is 0,83 .

- Low levels of social trust may also encourage preference for an expert government, as has been pointed out by previous research (García-Espín, Ganuza, \& de Marco, 2017). We include the classic scale (0-10) used to measure social trust.

- Font et al. (2015) highlighted a negative relation between participative and technocratic pref- erences. We use the bipolar participation versus representation scale mentioned in their work: "On a scale from 0 to 10 , where 0 means that citizens should take directly all decisions and 10 that politicians should take all decisions, where would you place yourself?"

- These process preferences should be related to the desired role for citizens in political life. To measure it, we incorporate the most traditional measurement (postmaterialism) of these values, in the analysis (materialist citizens versus the rest). The survey included the usual two-fold question about materialist versus postmaterialist priorities. Given that the number of absolute postmaterialists was very low, we used a dichotomous variable created on the basis of these priorities, which distinguishes between those who chose two materialist options from others who did not do so (postmaterialists or mixed cases, in the traditional terminology).

- We included a variable for education, as other international research (e.g., Coffé \& Michels, 2014) and our own focus groups show that it could be an important explanatory factor.

- Finally, since age has been shown to be related to preferences for expert government (Rapelli, 2016), we also include this variable with no further transformation.

Table 2 shows the results of a linear regression for the traditional variable representing support for the idea of an expert government. The first thing which stands out is the especially high (and significant) effect of the perceived capacity (technical skills) of experts, as it was suggested by our second hypotheses. An individual who rates all other variables 0 and also gives 0 to capacity of experts may have a 3 on the scale $(0-10)$ of support for 
Table 2. Explanatory factors of support for experts (linear regression).

\begin{tabular}{|c|c|c|c|}
\hline \multirow[b]{2}{*}{ Variables } & \multicolumn{3}{|c|}{ Scale $0-10$ support for experts } \\
\hline & Coef. b & Coef B & Sign \\
\hline Constant & 2.73 & & 0.00 \\
\hline Capacity (skills) of experts & $0.50 *$ & 0.37 & 0.00 \\
\hline Left & 0.25 & 0.04 & 0.25 \\
\hline Voters of Ciudadanos & $0.73^{*}$ & 0.07 & 0.02 \\
\hline Voters of PP & -0.30 & -0.04 & 0.26 \\
\hline Voters of UP & 0.32 & 0.04 & 0.22 \\
\hline Voters of PSOE & $0.57^{*}$ & -0.09 & 0.01 \\
\hline \multicolumn{4}{|l|}{ Control Variables } \\
\hline Efficacy, not debate & -0.20 & -0.05 & 0.07 \\
\hline Politics difficult for people like me & 0.10 & 0.03 & 0.30 \\
\hline Political Trust & $0.03^{*}$ & 0.08 & 0.02 \\
\hline Social Trust & -0.02 & -0.01 & 0.64 \\
\hline No Materialism & $0.54 *$ & 0.09 & 0.00 \\
\hline Participation vs representation & $0.09 *$ & 0.09 & 0.00 \\
\hline Education & -0.14 & 0.06 & 0.06 \\
\hline Age & 0.01 & 0.03 & 0.26 \\
\hline № of cases & & 1027 & \\
\hline $\mathrm{R}^{2}$ & & 0.21 & \\
\hline
\end{tabular}

* Coefficients where $p<0.05$.

political decision-making by experts. If the same individual rates the capacity of experts with a 5 , their support for political presence will increase to 5.5 , and if experts are considered very capable (10) then the support for this formula of government will jump to 8 . The result is particularly robust given that it remains stable regardless of any other control variables that may be included in the model.

There are six other significant variables, although with a lesser explanatory capacity. Firstly, Ciudadanos voters are more in favour of an expert government than the rest of the population, confirming results by Lavezzolo and Ramiro (2017), supporting our third hypotheses. Parties also matter in the case of socialist voters who appear to have a significant lack of confidence towards experts, a tendency which has also been suggested by our focus groups. In both cases, being a voter of one of these parties increases (or decreases) the overall tendency to support experts by more than half a point (in a 0-10 scale).

Among control variables, post-materialist individuals are more inclined towards forms of government with a stronger presence of experts, a result hitherto not observed. The participation versus representation scale has a modest influence, contrary to the direction expected (Bertsou \& Pastorella, 2017): more inclination towards representative models (rather than participative) translates to a stronger support for experts in politics. This result is coherent with the positive effect registered for political trust and coincides with the association between technocratic and representative prefer- ences suggested by Font et al. (2015) for the Spanish case, as well as with the qualitative analysis: support for the role of experts is especially clear among those satisfied with representation.

Table 3 shows the results of the second dependent variable, support for a wholly expert government, based on a logistic regression. Here, the explanatory variables which reach statistical significance are reduced considerably: experts' perceived capacities (skills) and two ideological variables are important-left-wingers are more reluctant to the idea of expert government and voters of Ciudadanos particularly inclined to it-as well as one of the control variables, age. Figure 3 shows the marginal effect of the main explanatory variable (perceived capacity of experts), showing its clear consequences in the expected support for an expert government.

Some of the explanatory variables (perceived capacity and vote for Ciudadanos) are the same ones, but others change from the previous case, as suggested in our fourth hypothesis. Leftist voters, for example, are not overtly against experts (first dependent variable), but are more clearly reluctant to the idea that they should directly make collectively binding decisions.

Both models are free from multicollinearity problems: all correlations among independent variables are below 0.4, VIF for all variables are all close to 1 and always below 1.5 and the highest Condition Index among all variables is 25.6 for education, still below the conventional 0.30 threshold.

It could be argued that the perceived capacity (skills) of experts is a characteristic which is conceptually too 
Table 3. Explanatory factors of support for decision-making by experts (logistic regression).

\begin{tabular}{|c|c|c|}
\hline \multirow[b]{2}{*}{ Variables } & \multicolumn{2}{|c|}{ Support for expert government } \\
\hline & Coef. b & Sign \\
\hline Constant & -3.32 & 0.00 \\
\hline Capacity (skills) of experts & $0.21 *$ & 0.00 \\
\hline Left & $-0.54 *$ & 0.01 \\
\hline Voters of Ciudadanos & $0.51 *$ & 0.04 \\
\hline Voters of PP & -0.23 & 0.33 \\
\hline Voters of UP & 0.08 & 0.74 \\
\hline Voters of PSOE & 0.03 & 0.88 \\
\hline \multicolumn{3}{|l|}{ Control Variables } \\
\hline Efficacy, not debate & 0.07 & 0.51 \\
\hline Politics difficult for people like me & -0.00 & 0.97 \\
\hline Political Trust & -0.01 & 0.40 \\
\hline Social Trust & -0.02 & 0.45 \\
\hline No Materialism & 0.05 & 0.78 \\
\hline Participation vs representation & 0.01 & 0.86 \\
\hline Education & 0.07 & 0.32 \\
\hline Age & $0.01 *$ & 0.02 \\
\hline № of cases & \multicolumn{2}{|c|}{1049} \\
\hline $\mathrm{R}^{2}$ Nagelkerke & \multicolumn{2}{|c|}{0.08} \\
\hline
\end{tabular}

* Coefficients where $p<0.05$.

close to the reality to be explained, so that this factor could be unmasking the importance of other variables. To avoid this risk, we have replicated the two models, excluding this variable. Crucially, the results do not change: among the 26 coefficients included in Tables 2 and 3 only one control variable changes from signifi- cant to not significant (or vice versa)-materialism would no longer be significant in Table 2 with this exclusion. Clearly, the explanatory capacity of the models is drastically reduced, but the substantive story behind them suffers no significant changes, if we choose to drop this variable from the analyses.

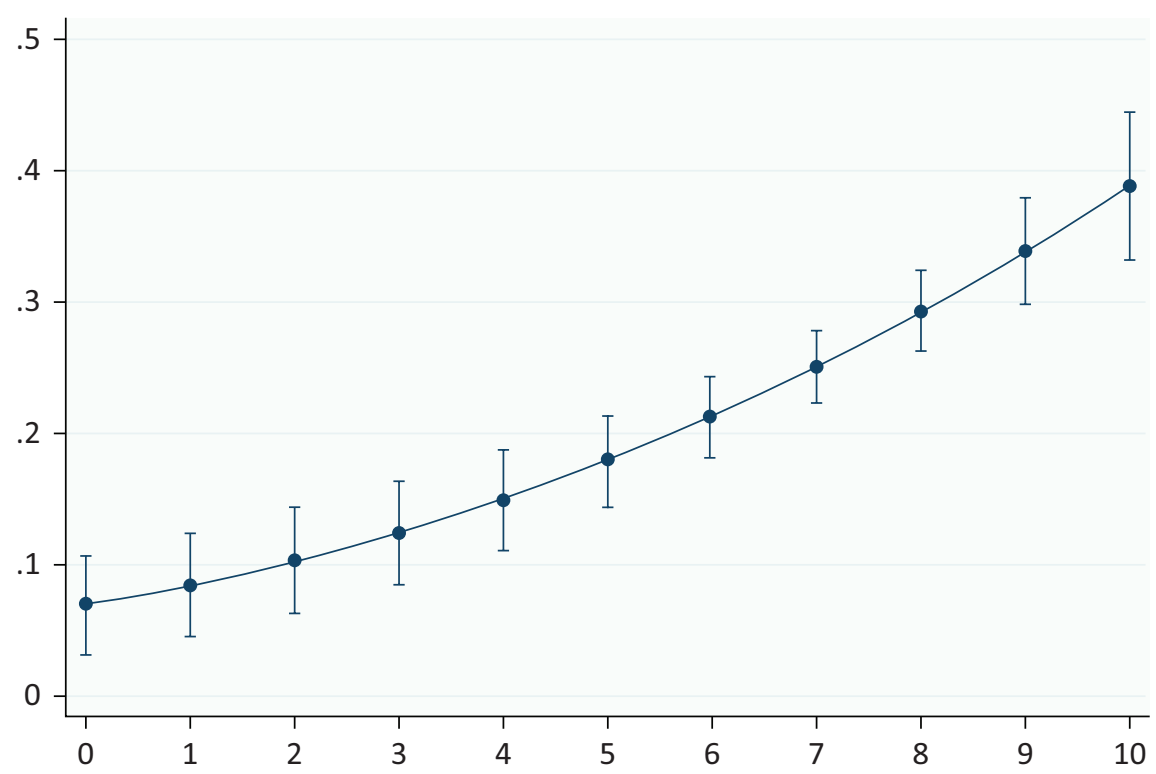

Figure 3. Marginal effects of perceived capacity (skills) of experts in support for expert government ( $95 \%$ confidence intervals). Notes: $X$ axis shows the values of the perceived capacity (skills) of experts. $Y$ axis represents the level of predicted support to expert government. 


\section{Discussion}

Previous research has shown the relationship of technocratic attitudes with citizens' desire for political relations without any mediation, with less public debate and more political efficiency (Akkerman et al., 2014; Bertsou \& Pastorella, 2017). Our study contributes to widening the scope on this issue. The prestige attributed to experts in our society, as opposed to parties and representatives, may suggest a negative relationship between these phenomena with the idea of politics without politicians. This is, nevertheless, wrong. The majority of citizens are in favour of a generic idea of politics with experts. People think experts are important because of their knowledge and technical skills. But when it comes down to detailing their precise functions procedurally, they lean towards a consultative role. Both focus groups and quantitative analysis suggest that, for many citizens, demands for experts are not at odds with representative democracy.

We find similarities and differences in the patterns for social support of both types of pro-technocratic attitudes. There are two factors clearly linked to them: trust in experts' skills (perceived capacity) and support for a pro-technocracy party such as Ciudadanos. The first is a conclusion which had been reached for other types of political processes-a higher degree of confidence in representative or participative democracy, dependent on the degree of trust bestowed on, respectively, politicians' or citizens' capacities (Del Rio et al., 2016). Our analysis allows to extend this pattern to the case of experts: trusting the capacity of the crucial actors in the political process is an almost necessary condition to support it.

The relationship of technocratic attitudes with Ciudadanos voters had already been pointed out by Lavezzolo and Ramiro (2017). However, our analyses show that this idea holds in all of the three different scenarios: the conclusion remains valid with two different measures of support for technocracy, in a political context where visibility and support for Ciudadanos is greater, and also when the equations include a larger number of control variables. The direction of causality between these variables may be argued, although their persistent relation is an interesting fact which helps understand the nature of support for political forces with technocratic components which are not situated at the extremes of the political spectrum, as may be the case with Macron in France or with several Eastern European parties (Engler, 2020).

However, the distinct content of these two types of support also implies that the remaining variables associated with them are different. The only additional variable related to support for the stronger version of technocracy is (absence of) left ideology, which is more disinclined towards the idea that experts should have the last word in decision-making, a relationship that also came up in the focus groups. If, on the other hand, we look at the more generic support for experts, we observe that it is less pronounced amongst socialist voters and people with a lower level of education (both, in quantitative as well as in qualitative analysis) and amongst people who are confident in the representative system; this reaffirms the idea that for these supporters technocracy is not in any way seen as an alternative to representative government, but rather as a possible and desirable component of the latter.

Our results do not suggest that the technocratic inclination of citizens is not an important factor, as many articles in this monograph demonstrate. Rather, we confirm the existence of an important inclination of citizens for technocratic efficiency. The problem that our research opens up is that this desire for political efficiency does not yet appear to have fractured the basic procedural principles of party democracy. On the contrary, apparently representative democracy and technocracy ('the ideology of expertise') mix well for many citizens. If the ideology of expertise can be used by populist parties to legitimate a rejection of party democracy, we need more research to be clear to what extent individuals will definitely support a non-pluralistic system. Following our results, they won't.

The results leave several unanswered questions to which we need to heed close attention in future research. Firstly, if until now postmaterialist values have been associated with a predisposition to participative processes, our results suggest that such values may also influence positively the degree of support for the political presence of experts. That is, it could be that people with more cultural resources (traditionally postmaterialists) do not want to be involved in politics directly, but may be more prone to having different voices heard in the decisionmaking process (not only politicians) and experts seem to be a key figure in this postmaterialist narrative. Secondly, there are many coincidences between the results of the quantitative and qualitative analyses; it would, therefore, be desirable to extend the triangulation of methods to other studies in this field. For example, there are characteristics, such as the clear distinction between the two sets of centre-right voters (PP versus Ciudadanos) which were observed less clearly in the focus groups and should consequently be the subject of future research. The distinction between these different families of centre-right voters regarding their relationship with expert government should also be explored in different political contexts to determine whether this is emblematic or not of the Spanish case. Thirdly, it would be worthwhile to investigate if the distinction between weaker and stronger forms of support for technocracy is only typical of highly pro-technocratic societies, such as Spain and Andalusia, or whether it is also present in other polities less enthusiastic about experts (Finland, for example).

\section{Acknowledgments}

This article was possible thanks to a grant from Andalusian Research Centre (PRY079/14). We thank José Luis Fernández and Sara Pasadas for research assistance 
and the journal referees and editors for valuable comments on a previous version of this article.

\section{Conflict of Interests}

The authors declare no conflict of interests.

\section{References}

Akkerman, A., Mudde, C., \& Zaslove, A. (2014). How populist are the people? Measuring populist attitudes in voters. Comparative Political Studies, 47(9), 1324-1353.

Bengtsson, A., \& Mattila, M. (2009). Direct democracy and its critics: Support for direct democracy and "stealth" democracy in Finland. West European Politics, 32(5), 1031-1048.

Bertsou, E., \& Caramani, D. (in press). People haven't had enough of experts: Technocratic attitudes among citizens in nine European democracies. American Journal of Political Science. Advance online publication. Retrieved from http://eribertsou.com/ wp-content/uploads/2020/07/BertsouCaramani_ People-Haven't-Had-Enough-of-Experts.pdf

Bertsou, E., \& Pastorella, G. (2017). Technocratic attitudes: A citizens' perspective of expert decisionmaking. West European Politics, 40(2), 430-458.

Bickerton, C., \& Invernizzi Accetti, C. (2017). Populism and technocracy: Opposites or complements? Critical Review of International Social and Political Philosophy, 20(2), 186-206.

Bickerton, C., \& Invernizzi Accetti, C. (2018). 'Technopopulism' as a new party family: The case of the Five Star Movement and Podemos. Contemporary Italian Politics, 10(2),132-150.

Buštíková, L., \& Guasti, P. (2019). The state as a firm: Understanding the autocratic roots of technocratic populism. East European Societies and Cultures, 33(2), 302-330.

Caramani, D. (2017). Will vs. reason: The populist and technocratic forms of political representation and their critique to party government. American Political Science Review, 111(1), 54-67.

Coffé, H., \& Michels, A. (2014). Education and support for representative, direct and stealth democracy. Electoral Studies, 35, 1-11.

De la Torre, C. (2013). Latin America's authoritarian drift: Technocratic populism in Ecuador. Journal of Democracy, 24(3), 33-46.

Del Rio, A., Navarro, C., \& Font, J. (2016). Citizens, politicians and experts in political decision-making: the importance of perceptions of the qualities of political actors. Revista Española de Investigaciones Sociológicas, 154, 75-92.

Engler, S. (2020). Centrist anti-establishment parties and their protest voters: More than a superficial romance? European Political Science Review, 12, 307-325.

Eriksen, E. (2011). Governance between expertise and democracy: The case of European security. Journal of European Public Policy, 18(8), 1169-1189.

Fischer, F. (1990). Technocracy and the politics of expertise. London: Sage.

Font, J., Wojcieszak, M., \& Navarro, C. (2015). Participation, representation and expertise: Citizen preferences for political decision-making processes. Political Studies, 63(1), 153-172.

Ganuza, E., García-Espín, P., \& de Marco, S. (2017). Do people want more participation? Tensions and conflicts in governance in times of skepticism. Revista de Estudios Políticos, 176, 253-279.

Ganuza, E., \& Font, J. (2018). ¿Por qué la gente odia la política? [Why do people hate politics?]. Madrid: Catarata.

García-Espín, P., Ganuza, E., \& de Marco, S. (2017). Assemblies, referendums or consultations? Social representations of citizen participation. Revista Española de Investigaciones Sociológicas, 157, 45-64.

Hibbing, J. R., \& Theiss-Morse, E. (2002). Stealth democracy: Americans' beliefs about how government should work. Cambridge: Cambridge University Press.

Inglehart, R. (1990). Culture shift in advanced industrial society. Princeton, NJ: Princeton University Press.

Krause, N., Brossard, D., Scheufele, D., Xenos, M., \& Franke, K. (2019). Americans' trust in science and scientists. Public Opinion Quarterly, 83(4), 817-836.

Lavezzolo, S., \& Ramiro, L. (2017). Stealth democracy attitudes and the support for new and challenger parties after the 2008 Great Recession. European Political Science Review, 10(2), 267-289.

Norris, P. (2011). Democratic deficit: Critical citizens revisited. New York, NY: Cambridge University Press.

Radaelli, C. (1999). Technocracy in the European Union. New York, NY: Longman.

Rapeli, L. (2016). Public support for expert decisionmaking: Evidence from Finland. Politics, 36(2), 142-152.

Stoker, G., Hay, C., \&, Barr., M. (2016). Fast thinking: Implications for democratic politics. European Journal of Political Research, 55, 3-21.

Turner, S. (2001). What is the problem with experts? Social Studies of Science, 31(1), 123-149.

Urbinati, N. (2014). Democracy disfigured: Truth, opinion and the people. Cambridge, MA: Harvard University Press.

Webb, P. (2013). Who is willing to participate? Dissatisfied democrats, stealth democrats and populists in the United Kingdom. European Journal of Political Research, 52(6), 747-772. 


\section{About the Authors}

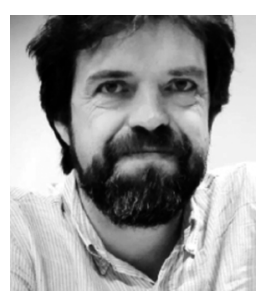

Ernesto Ganuza is a Research Fellow at the Spanish Research Council (IPP-CSIC). He studied in Madrid, Spain, and he's been Visiting Researcher in Berlin (Centre Marc Bloch), Paris (CNRS) and Providence (Brown University). He works on issues of Democracy, Civil Society or the contemporary political space open to participation and the democratization challenges resulting. He has published essays and books on these topics. He's recently published (with Gianpaolo Baiocchi) Popular Democracy: The Paradox of Participation (Stanford University Press).

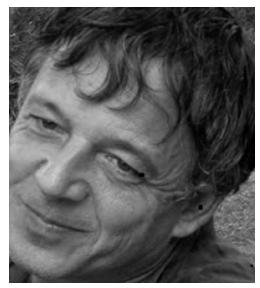

Joan Font is a Senior Researcher at the Institute of Advanced Social Studies (IESA-CSIC). He has conducted research about elections, surveys and participatory institutions and has published in journals like European Journal of Political Research, Public Administration or International Journal of Urban and Regional Research. He is Co-ditor (with Donatella della Porta and Yves Sintomer) of Participatory Democracy in Southern Europe (Rowman \& Littlefield). 